\title{
The Discourse of Nation Building in the Goods and Services Tax (GST) Malaysia Info Web Portal News Articles
}

\author{
ONG CHENG TEIK \\ School of Education, Languages and Communications, \\ Wawasan Open University, Malaysia \\ Email:egb789@hotmail.com
}

HAJAR ABDUL RAHIM

School of Humanities,

Universiti Sains Malaysia

\begin{abstract}
This paper explores the choice of language employed by the Malaysian mainstream media to construct the former Barisan Nasional government's role in nation building in transforming Malaysia from a developing country to a fully developed country by the year 2020 as envisioned by Vision 2020. In particular, this paper focuses on fourteen curated news articles on the GST Malaysia Info web portal set up by the former government to educate the public on the benefits of the Goods and Services Tax (GST) to the country and the people by analysing lexical words with experiential values. The data collection, categorisation and analysis entail the use of simple corpus linguistic tools and close reading of the data based on the researchers' interpretative resources or "member's resources" (Fairclough, 2001). The analysis of this study utilising a qualitative approach shows that the people are not only persuaded to 'buy' the idea of the new GST tax regime but also to buy into the ideology and discourse of nation building from the introduction of a more efficient way of tax collection. It uncovers how the manipulation of an educational campaign on the GST into a political discourse of nation building produces a positive portrayal of the government with an efficient economic development plan. Drawing on Fairclough's $(1989,2001,2015)$ three-dimensional Critical Discourse Analysis framework with a focus on different values of formal linguistic features, this study offers insights into the interplay between language, politics and nation building.
\end{abstract}

Keywords: Goods and Services Tax (GST); mainstream media; Critical Discourse Analysis; nation building; experiential value of words

\section{INTRODUCTION}

The exercise of power through language instead of physical coercion is commonly employed by governments in this digitally empowered age to persuade and convince people about certain policies and issues. Central to such exercise of power is the attempt to change, transform, manage and control people's mental model to be consonant with those of powerful political elites. This sophisticated form of power exercise is considered necessary and more effective for the dominant group to perpetuate and extend its rule over the dominated group through the manufacturing of consent and persuasion as the exercise of power by force will not lead to everlasting rule (Fontana 1993, as cited in Khoo \& Bahiyah 2019, p. 49).

This study contextualises such sophisticated operationalisation of power through the promotion of the Goods and Services Tax (GST) discourse by Malaysia's former Barisan Nasional (BN) government. In particular, the data is mined from the previous government's website GST Malaysia Info that published curated positive GST news articles by the BN friendly mainstream media. The website was set up as part of the previous government's campaign to educate people on the benefits of the GST with a view to garnering support for the tax regime change through transforming people's mindset from anxiety, hostility and opposition to ambivalence and acceptance, if not total embrace.

Among the various discourses subsumed under the nodal GST discourse, this paper focuses on the discourse of nation building in the selected news articles and how it is 
linguistically realised as it is a major issue foregrounded on the website. Used interchangeably, nation building and national development refers to the improvement of a country and her people in all aspects such as economy, social and culture and an equitable distribution of benefits and wealth (The United Nations Declaration of the Right to Development 1986).

In particular, this paper examines the text producers' attempt at manufacturing people's support for and approval of the GST in the run-up to the implementation of the GST on 1 April 2015 by highlighting the benefits of the GST to the people and country in line with the previous government's nation building agenda. Through the GST education campaign in general and the discourse of nation building in particular, the previous government worked to bring about a change in people's mindset by debunking misconceptions and urban myths about the demerits of the GST. This is because the implementation of the GST was widely perceived as a heavy financial burden for the average and poor households who have to grapple with bread and butter issues.

The gravity of the implementation of the GST that bears on people from all walks of life in Malaysia and the dearth of studies on CDA and nation building have led to the conception of this study. The marked absence of such discourse analysis in general and Critical Discourse Analysis in particular on the Goods and Services Tax in Malaysia will be discussed in the literature review section. As such, the current study serves to narrow the literature gap and hopes to contribute some knowledge to the studies of linguistics, media and economic policies. In addition, this study may provide useful information to the present government about the appropriate use of linguistic choices to promote its nation building policies and agenda to bolster the citizens' understanding and trust in government policies. Critical text consumers may be able to excavate such discursive strategies in text with appropriate exposure. As such, CDA provides a useful pedagogical tool to this end.

\section{SOCIO-ECONOMIC AND SOCIO-POLITICAL CONTEXT}

\section{THE GOODS AND SERVICES TAX (GST) IN MALAYSIA}

The eventual change in the country's tax regime by the former Barisan Nasional government on 1 April 2015 took place amidst the country's changing and increasingly challenging economic landscape which presented the government with a host of challenges leading to a drastic fall in the country's revenue.

These economic challenges notwithstanding, "the main reason for introducing the GST is to diversify the country's revenue sources" (Gstmalaysiainfo 2015). Former Prime Minister, Datuk Najib bin Tun Razak insisted that "the extra revenue gained from the Goods and Services Tax is necessary to boost the nation's competitiveness" (Gstmalaysiainfo 2015).

The government then expected the GST, perceived as a more efficient tax, to generate more revenue for nation building and development purposes such as amenities, infrastructures and education with a view to improving the people's standard of living and realising the country's aspiration to achieve a high income and fully developed nation in the year 2020 .

However, the GST is subsequently superseded by the Sales and Services Tax (SST) after the $14^{\text {th }}$ General Election on 9 May 2018 when the Pakatan Harapan (PH) government took over from the previous BN government in part fulfilment of its General Election manifesto.

Despite the repeal of the GST by the PH government, the implementation of the GST is not entirely without merits as conceded by the PH government itself when the new Minister of Finance admitted that "GST is an efficient system for the government but a burden to the 
people" (The Star Online, 2018). This bears testimony to the efficacy of the GST and lends credence to some of the claims by the previous BN government in news reports.

As a consumption tax vis-à-vis an income tax, the GST is considered a more superior and efficient taxation instrument. The GST contributes significantly to the government's revenue by casting its nets over a wide-ranging goods and services, hence compensating for uncollected income tax through tax evasion as reiterated by the Minister of Finance: "The GST is more efficient and transparent when it is charged on $60 \%$ of the consumer price index goods basket compared to just 38\% by the SST" (The Star Online, 2018). Customs director-general Datuk Seri Subromaniam Tholasy further elaborated that "some 472,000 businesses were subjected to the GST while fewer than 100,000 would be affected by the SST" (The Star Online, 2018).

The admission by the Minister of Finance in the preceding paragraph sheds light on the underlying cause of the people's resentment. Instead of casting aspersions on the efficacy of the GST as a taxation instrument, the contentious issue and hence the underlying cause of discontentment lies in the country and people's readiness in embracing the GST. In the face of a host of economy problems such as rising cost of living, the BN government's discontinuation or reduction of subsidies and the shrinking value of the Ringgit, the average and poor households have to grapple with bread and butter issues and the implementation of the GST clearly poses a financial burden to the people.

The situation is unlike other GST models in developed countries surveyed by the former BN government for adoption as the people there have higher average income and hence larger disposable income to cushion the effect of the GST. Of the three GST compliant countries that the former BN government surveyed, Australia is ranked $11^{\text {th }}$ (US\$4,519), New Zealand $24^{\text {th }}$ (US\$3,220) and South Korea $28^{\text {th }}$ (US\$2,300) in terms of average income in the world in the year 2015 as compared to Malaysia's $41^{\text {st }}$ ranking (US\$822) (WorldData.info, 2015). In 2016, the Malaysian Statistics Department reported a lower average monthly salary of RM2,657 (The Star Online, 2018). This effectively placed Malaysia in the low-income economy group with GNI (Gross National Income) of US\$995 or less based on the World Bank's grouping for 2017 (The World Bank, 2018). In addition, the series of false starts and delays in the implementation of the GST in Malaysia by the former BN government are also indicative of the previous government's reservation over the people's readiness and its concern over a potential political backlash which in retrospect is not unfounded.

\section{NATION BUILDING IN MALAYSIA}

Over the years, nation building in Malaysia hinges on carefully formulated economic policies and plans by the government to chart the development of the country's economy. Among these plans are the government's annual budgets, the eleven five-year Malaysia Plans (MP) from 1966 to 2020, the New Economic Policy (NEP) from 1971 to 1990, the National Development Policy (1991 - 2000), Vision 2020 (1991 - 2020) and the National Transformation Programme (TN50) from 2021 to 2050. These development plans and policies are archived in chronological sequence in the Perdana Leadership Foundation (2018) web portal. These blueprints strategically set out the short-term, middle-term and long-term macro and microeconomic goals and objectives for nation building in Malaysia to sustain the country's development, to steer the economy to greater heights and to take the country to the next level in the year 2020 and beyond as a fully developed and high income country. More importantly, these policies seek to ensure the efficient generation of revenues to finance and sustain the country's development and expenditure.

To grow and diversify the country's revenue sources, it is evident that the former government's introduction of the GST generated a significant amount of revenue to fund and 
support nation building, hence marking an important milestone in the country's economic development and transformation. Situated in this nation building agenda, the analysis of the fourteen selected news articles on the GST illuminates how the former government discourse on the GST infuses, blends and harmonises the different aspects or voices of nation building and economic development. Specifically, this paper focuses on how the discourse of nation building is linguistically realised in the news articles and how it promotes the former BN government's implementation of the GST. The dearth of studies on CDA and nation building and the significance of the implementation of the GST that bears on people from all walks of life in Malaysia have necessitated a study in this area.

\section{LITERATURE REVIEW}

The literature on language and nation building in general and Critical Discourse Analysis (CDA) and nation building in particular is informed by multifarious studies situated in diverse contexts and genres, ranging from economy to finance, government policies and general election manifesto. This is testament to how the CDA framework is highly amenable to studies with different purposes, audiences, contexts and cultures.

The discussion on selected past studies outside Malaysia is organised under three main categories, namely interdiscursivity, legitimation strategies and the Goods and Services Tax (GST), all of which are pertinent to nation building. The discussion will also indicate a gap in the studies which the present research hopes to address.

Among the studies on interdiscursivity related to economy and finance in general and nation building in particular are those covering the Lisbon Declaration (Fairclough 2006), the Eurozone crisis (Vaara 2014) and Singapore's clean and green campaigns (Teo 2007). Fairclough's (2006) study on the Lisbon Declaration comprises the nodal discourse of the knowledge-based economy which also articulates other associated secondary discourses such as the discourses of growth, (un)employment, social and regional cohesion, the information society, competitiveness and social exclusion. In his study on the Eurozone crisis, Vaara (2014) focuses on the bailout decisions and rescue packages proposed for Greece, Ireland, Portugal and Cyprus. Predicated on a critical discourse analysis perspective, the study shows how discourses of financial capitalism, humanism, nationalism and Europeanism inform the legitimation strategies frequently used in the media. Adopting Fairclough's (1995) Critical Discourse Analysis approach, Teo's (2007) study provides insights into how the different discourses or voices of environmental protection and nation building are blended and harmonised, hence the interdiscursive strand of the study.

The study on legitimation strategies as a means to naturalise and legitimise the ideology of the text producer is situated in the domain of legislation i.e. the 1942 Wealth Tax in Turkey (Akan 2011). His study examines how the Turkish government employed various discursive strategies and legitimation strategies, weaving in a number of discourses such as nationalism, social justice, loyalty, Turkish identity, profiteering and exploitation. Although Akan's (2011) study is on the 1942 Wealth Tax in Turkey, its inclusion sheds light on how the Turkish government promoted and justified the adoption of the Wealth Tax in Turkey, hence making its discussion somewhat relevant to this research on the GST.

The review of studies conducted on the GST to date reveals that there is one study on the GST directly related to the field of linguistics and Critical Discourse Analysis. The study is by McKell (2007) on the use of tax metaphors in John Howard's speeches on the GST during the 1998 Federal Election. The study identifies three main conceptual metaphors in Howard's discussion of the GST, namely tax-as-medicine, GST-as-revolution and existing tax regime as 
a broken machine. The study concludes that these metaphors function to represent the GST as dynamic, forward-looking and positive.

Other studies on the Goods and Services Tax and other forms of tax are mainly situated in the domain of economy, business, finance, politics and social sciences. The studies reviewed are on New Zealand's experience in introducing the GST (Louise 2015), major economic reforming initiatives by the Mulroney's administration in Canada (Porter 2007), tax policy change from the Manufacturers' Sales Tax (MST) to the GST in Canada (Eccleston 2007), the advertising of the GST in Canada (Rose 2000), Canadian government's communication programmes on the GST (Roberts \& Rose 1995) and the rationale for tax reform by governments (Diamond \& Zodrow 2008). As such, the present study based on the CDA framework hopes to address the literature gap in this area.

On the home front, the literature is replete with studies on nation building and development in non-linguistic disciplines such as history, philosophy, civilisation, the humanities, arts, social sciences, social policies and political sciences. These studies foreground diverse issues ranging from the state of development in Malaysia (Lee 2004) to the politics of development in Sarawak (Hazis 2009), the preferential bumiputera policy in nation building (Cheah 2003), affirmative actions for Sarawak's bumiputera communities (Berma 2003), enterprise development (Gomez 2003), the Indian identity in Malaysia (Kailasam 2015), social capital for development (Farouk \& Husin 2015), empowering the humanities for social development (Omar 2011) and the political merger of Singapore with Malaysia (Low 2017).

The local literature review uncovers limited studies on language and nation building i.e. one with reference to Barisan Nasional's 2004 general election manifesto (Aman 2004) and another on Malaysia's Economic Transformation Programme (Rajandran 2013), the former of which employs Fairclough's $(1992,1995)$ three-dimensional Critical Discourse Analysis (CDA) framework whereas the latter is grounded on critical metaphor analysis (CMA) by Charteris-Black (2004). This clearly indicates a literature gap in Malaysian studies on language and nation building in general and CDA and nation building in particular which this study attempts to address.

Aman (2009) employed Fairclough's (1992, 1995) three-dimensional Critical Discourse Analysis framework to show how Barisan Nasional's 2004 general election manifesto contributed to its striving for political power and victory. Particularly, it focuses on the textual features and discourse practice. The textual analysis focuses on grammar, vocabulary and the generic structure of the text. The study found a preponderance of active clause to highlight Barisan Nasional's commitment to its promise stated in the manifesto.

Related to language and nation building, Rajandran's (2013) study examines former Malaysian Prime Minister Datuk Seri Najib's use of metaphors to represent the Economic Transformation Programme (ETP) positively based on critical metaphor analysis (CMA) (Charteris-Black 2004). The study reveals that the use of metaphors both legitimises the government's intervention in nation building and advances an asymmetrical power relation between the government as experts in economic matters and the people as non-experts who are expected to follow the government's lead in driving the economy.

The literature review above indicates limited local studies on language and nation building, particularly on CDA and nation building. As such, the novelty of the present study lies in its attempt to bridge the literature divide. It undertakes to address this in two areas i.e. by conducting an inter-disciplinary CDA study on the discourse of nation building and by focusing on the genre of newspaper reports as its corpus. 


\section{METHODOLOGY}

This study employs Fairclough's (1989, 2001, 2015) three-dimensional Critical Discourse Analysis framework based on its systematic description of experiential, relational and expressive values of words and grammatical features with a comprehensive range of lexical and grammatical features for each value. In particular, it draws on the experiential value of words indicative of contents, knowledge and beliefs of the producer, hence it is relevant to identifying and analysing the nature of discourse. The purpose of this study is to identify the different aspects of the discourse of nation building present in the news articles on the Goods and Services Tax (GST) on the previous government's website GST Malaysia Info. The specific objective is to analyse the linguistic features used to realise the discourse of nation building present in the news articles on the website.

The study utilises a qualitative approach to provide a fine-grained analysis and rich discussion of contextually based data (Mann \& Stewart 2000, Creswell 2007). It entails close reading of the data and the use of simple corpus linguistic tools. The former is based on the researchers' interpretative sources or "member's resources" (Fairclough 2001) such as the researchers' background knowledge of and experience with the implementation of the GST in Malaysia from the perspective of a consumer, the researchers' awareness of the issues surrounding the GST and the alternative discourse on the GST. The latter involves the employment of corpus linguistic tools, namely frequency count and concordance to generate data for the analysis of the headlines to arrive at the various secondary GST discourses and the various aspects of the discourse of nation building. In this regard, the study uses the AntConc program version $3.4 .4 \mathrm{w}$ which is freely available on the Internet.

The data comprises fourteen curated GST news articles on the former government's GST website GST Malaysia Info, the official portal set up by the former BN government to provide information on the GST to the public. The portal comprises, among others, a collection of selected news articles on the GST sourced from several mainstream media such as The New Straits Times Online, The Star Online and Bernama, the Malaysian National News Agency. However, the website has since been revamped with a totally different interface and objectives as it no longer carries news archive and updates on the GST.

In short, the general design of the study observes the following steps which are often recursive and which overlap with each other: identification and application of theories, design of research questions, data collection and labelling, data categorisation, data selection, data description and analysis and data interpretation.

The data collection and data categorisation stage entail close reading of the data to achieve the objective of identifying the different secondary GST discourses in general and different aspects of the discourse of nation building in particular in the news articles on the GST on the website GST Malaysia Info. This is based on the researchers' interpretative sources or "member's resources" (Fairclough 2001) as discussed in the preceding paragraph.

At the data selection stage, to enrich the discussion of the findings, effort was taken to make sure that the articles selected on the discourse of nation building encompass various events and contexts. Also, the study focuses on news articles produced by local authors "to ensure the findings were representative of the local voice" (Nadhratunnaim \& Surinderpal 2019, p. 153). Eventually, fourteen (14) curated GST news articles from the mainstream media on the former government's GST website GST Malaysia Info were shortlisted to cover events related to the following contexts:

(a) The long journey of the GST from its conception in 1983 to implementation in 2015.

(b) The former government's GST campaigns in educating the public about the need for and the benefits of the GST for the country and people. 
(c) The public's positive adaptation to and acceptance of the implementation of GST as a result of the former government's GST campaigns.

(d) Comparisons with other GST compliant countries to highlight the positive features of Malaysia's GST.

(e) The GST as an economic reform to reduce the country's fiscal deficit and oil subsidies.

(f) The former government's explanation of the GST collection as revenue for the funding of various development projects.

(g) The former government's clarification, justification and rationalisation of the positive impact of the GST on the various sectors of the economy.

The discussion will present findings related to the experiential values of words focusing on overlexicalisation and categorisation which figure prominently in the articles as linguistic manifestations of discourse to the exclusion of other less dominant linguistic features such as rewording, objectification and listing.

Related to classification under which vocabulary is organised in discourse types, overlexicalisation (Fowler 1979, 1991) or overwording (Fairclough 1989, 2001, 2015) refers to "an unusually high degree of wording, often involving many words which are near synonyms. Overwording shows preoccupation with some aspect of reality - which may indicate that it is a focus of ideological struggle" (Fairclough 2015, p. 133). In other words, overlexicalisation entails the provision of words that occurred frequently in a text in the same form or in different forms but with similar meanings such as synonyms associated with certain specialised area of experience. It also means words with ideologically significant meaning relations and words that belong to the same category. As such, overlexicalisation reveals the text producers' focus on and attention to selected aspects of reality, hence the promotion of certain discourse. An analysis of overlexicalisation in this study uncovers the presence of certain discourse associated with the nodal GST discourse. For instance, the promotion of the discourse of nation building is evident with an overlexicalisation of positive words describing the GST in relation to nation building, examples of which are "effective and sustainable taxation system", "progressive", "extra revenue" and "boost the nation's competitiveness".

In relation to classification and overlexicalisation, categorisation or classification scheme "constitutes a particular way of dividing up some aspect of reality which is built upon a particular ideological representation of that reality. In this way, the structure of a vocabulary is ideologically based" (Fairclough 2015, p. 133). Specifically, categorisation or classification by lexical registers serves to highlight distinction between classes of concepts and dichotomises people or concepts into different groups and the inevitable struggle among them. As such, categorisation is a central linguistic tool in identifying and naming the different people and parties in a discourse, their attributes, behaviours and actions. Such lexical categorisation or taxonomic organisation of vocabulary "mark(s) off socially and ideologically distinct areas of experience .... (and) is an integral part of the reproduction of ideology in the newspaper" (Fowler 1991, p. 84) as well as the promotion of certain discourse by the text producers as "it is generally useful to alternate our focus between the text itself and the discourse type(s) it is drawing upon, including classification schemes in terms of which vocabulary is organized in discourse types" (Fairclough 2015, p. 132). Among the lexical classification or categorisation of participants in the findings of this study are policy makers responsible for nation building and the GST as well as beneficiaries of the GST and nation building. Examples of the former are "The Royal Malaysian Customs and the Finance Ministry" and "Prime Minister Datuk Seri Najib Razak" whereas examples of the latter are "future generations", "poor families, children, senior citizens and the disabled" and "the people". 


\section{THE DISCOURSE OF NATION BUILDING: ANALYSIS}

The analysis centres on the linguistic features of overlexicalisation and categorisation which pervade the news articles as carriers of ideology. Tables are used to support the discussion of the findings and to illuminate the linguistic manifestations of the discourse of nation building in the set of fourteen shortlisted GST news articles which are representative of the following five central aspects of the discourse of nation building:

(a) The employment of positive words in describing the GST in relation to nation building.

(b) The specific positive features and benefits of the GST.

(c) The identification of policy makers responsible for nation building and the GST.

(d) The campaigns, media, studies, instruments, policies and directives related to the GST.

(e) The identification of the beneficiaries of the GST and nation building

\section{THE EMPLOYMENT OF POSITIVE WORDS IN DESCRIBING THE GST}

The common thread that runs through the discourse of nation building in the set of fourteen selected GST news articles is the positive representation of the GST in relation to nation building as evidenced by the preponderance of positive words describing the GST drawn from the domain of economy and finance in the form of nominalisations or noun phrases, adjectives or adjectival phrases and verb groups or clauses.

Examples of these are "a progressive model", "equity", "fiscal policy reforms", "gross domestic product (GDP) growth", "GST rate fixed at only six per cent", "minimal impact on the rakyat", "economic reforms", "saviour of national economy", "progressive", "creditpositive", and "the lowest in the world", "enhance fiscal sustainability", "boost govt's coffers", "enhance the government's revenue", "diversify the country's revenue sources" and "raise Malaysia's competitive edge". Table 1 below illustrates the contexts and the use of some of these words in the articles with underlined words indicating positive words that describe the GST and nation building:

TABLE 1. Examples of overlexicalisation of positive words describing the GST in relation to nation building

\begin{tabular}{llc}
\hline \multicolumn{1}{c}{ Extracts } & References \\
\hline 1. & \multicolumn{1}{c}{ As a step to developing a more effective and sustainable taxation system, } \\
the 2009 GST Tax Bill was tabled ... & Ar 11, para 6 \\
2. $\begin{array}{l}\text { The Malaysian GST designed to be progressive } \\
\text { The extra revenue gained } \ldots . . . \text { is necessary to boost the nation's } \\
\text { competitiveness. }\end{array}$ & $\begin{array}{c}\text { Ar 12, headline } \\
\text { Ar 21, para 1 }\end{array}$ \\
\hline
\end{tabular}

The proliferation of such positive words describing the GST and nation building exemplifies the employment of overlexicalisation by the news reports as a lexical instrument to promote the discourse of nation building favourable to the powers that be. The GST model implemented by the former BN government is touted as a "progressive" and "effective and sustainable taxation system" capable of generating "extra revenue" and "boost(ing) the nation's competitiveness". Such description carries ideologically significant meaning relations as it foregrounds a limited aspect of reality i.e. an optimistic view of the GST to nation building. However, a trade-off and link between the "extra revenue" generated by the GST and the resulting increase in prices and cost of living is accorded a silent treatment, hence signalling an ideologically partisan representation of the discourse of nation building by the news reports.

The former government's GST was hyped up in the news articles as a progressive model with the provision for the zero-rating and exemption of essential goods and services 
from the GST as opposed to many GST compliant countries in the world with a blanket GST rate. This set the tone for the representation of a people centric government that showed compassion for the average wage earners and the underprivileged. Such a strategic move would ease the financial burden and sustain the disposable income of the lower and average income households as prices of essential goods would not increase. This in turn would stimulate private consumption and economic growth.

\section{THE SPECIFIC POSITIVE FEATURES AND BENEFITS OF THE GST}

The news reports elucidated multifarious positive features and benefits of the GST either in generic terms or specific details with a view to casting the former government's implementation of the GST in positive light and educating the public to dispel any misconceptions that they may hold about the GST, hence changing their mindset to gain their acceptance.

The news extracts of the positive features and benefits of the GST are reproduced in Table 2 below with underlined words focusing on specific positive features and benefits of the GST:

TABLE 2. Examples of categorisation of specific positive features and benefits of the GST

\begin{tabular}{llc}
\hline & \multicolumn{1}{c}{ Extracts } & References \\
\hline 1. & $\begin{array}{l}\text { "The tax will be used to build infrastructure as well as improve transport, health, } \\
\text { education, security, religious and social amenities, " he told Bernama. }\end{array}$ & Ar 14, para 9 \\
2. & $\begin{array}{l}\text { GST Helps In Combating Black Economy } \\
\text { 3. } \begin{array}{l}\text { Governments throughout the world need to collect taxes .... to enable them to meet } \\
\text { the people's needs such as basic amenities, education, healthcare services and } \\
\text { security ... }\end{array}\end{array}$ & Ar 16, headline \\
& Ar 17, para 1 \\
\hline
\end{tabular}

The news articles are replete with such reports, enumerating the various goods and services zero-rated and exempted from the GST mainly in non-finite 'ing' clauses, clauses and nominalisation or noun phrases, among which are "zero-rating and exempting basic essentials from tax", "zero rating of basic essentials and exemptions" and "commodities on which poor households spend most of their income is not taxed".

This is followed by explication and exemplification of how zero-rating and exemption of essential goods from the GST benefited the majority of the consumers with an emphasis on the GST as an equitable and efficient method of local taxation and distribution of resources and wealth. Such illumination is indicative of an underlying dichotomy between the low to average income earners and the rich, the former of which overwhelmingly outnumber the latter whose spending power was not greatly affected by the extra 6\% GST. Examples of such elucidation are "the rich would have to pay tax and the richer you are the more you pay because the rich would spend more" and "low- and middle-income earners are unlikely to spend more on nonbasic items that are not GST zero rated or exempted".

As shown in Table 2 above, the discourse of nation building continues with the categorisation of various developmental projects in the form of clauses, nominalisation and noun phrases to account for how the GST revenues were ploughed back into the economy by the former government, ranging from "build infrastructure as well as improve transport, health", "education, security, religious and social amenities", "improve our social safety nets" to "the hidden or indirect subsidies".

Marking a departure from the benefits of the GST to the people, the news articles proceed to construct the GST as a more efficient tax regime for the country in plugging the loopholes and overcoming the inherent weaknesses in the then tax system as part of the discourse of nation building. Among its linguistic manifestation in clauses and noun phrases 
are "to handle tax evaders who grew rich by cheating the people", "those who have thus far had a free ride now need to contribute to the tax coffers" and "combating black economy", the last of which is illustrated in Table 2 above.

The news articles further identify and categorise the GST as a major reform in the country's tax system for efficient tax collection with clauses fronted by verbs with mitigating effect such as "lower individual tax", "to reduce corporate tax", "decrease the burden of tax" and "overcome the inherent weakness of SST", all of which are good news to the people.

\section{THE IDENTIFICATION OF POLICY MAKERS RESPONSIBLE FOR NATION BUILDING AND THE GST}

Another important aspect of the discourse of nation building highlighted in the news articles is the frequent identification of policy makers directly or indirectly involved in nation building and the GST. They are identified in two ways i.e. government bodies and specific individuals. The former comprises government ministries, agencies and parties such as "the Royal Malaysian Customs and the Finance Ministry", "the Government", the MoF and Customs", "government agencies", "the Domestic Trade, Co-operatives and Consumerism Ministry" and "the Public Accounts Committee". Such generic identification of government entities instead of individuals bears testimony to the collective responsibility and effort of the entire government machinery in nation building, hence giving due recognition to the involvement of all government officers, regardless of their ranks.

On the other hand, the news articles also identified specific individuals with the mention of designations followed by names, from high ranking government officers such as former Prime Ministers to ministers and directors, chief of which are "Tun Daim Zainuddin, then Minister of Finance", "Dato' Seri Anwar Ibrahim, then Minister of Finance", "Dato' Seri Abdullah Badawi, Prime Minister", "Prime Minister Datuk Seri Najib Razak" and "Deputy Finance Minister Datuk Ahmad Maslan”. It is noteworthy that on top of the list of frequently mentioned names is former Prime Minister Datuk Seri Najib Razak, hence pointing to his pivotal role in nation building.

Table 3 illustrates the categorisation of various policy makers directly and indirectly involved in nation building and the GST with underlined words representing policy makers responsible for nation building:

TABLE 3. Examples of categorisation of policy makers responsible for nation building and the GST

\begin{tabular}{clc}
\hline & \multicolumn{1}{c}{ Extracts } & References \\
\hline 1. & The Royal Malaysian Customs and the Finance Ministry has done extensive research & Ar 12, para 28 \\
2. & on the GST. & Ar 20, headline \\
3. & Prime Minister gov't help the people, says Idris & $\operatorname{Ar} 21$, para 2 \\
& could have positive spillover effects .... & \\
\hline
\end{tabular}

\section{THE CAMPAIGNS, MEDIA, STUDIES, INSTRUMENTS, POLICIES AND DIRECTIVES} RELATED TO THE GST

The campaigns, media, studies, instruments, policies and directives related to the GST as reported in this set of fourteen GST news articles on the discourse of nation building can be further divided into two temporal categories i.e. the pre-GST category at the early conception stage and the GST category at the subsequent preparation stage before, during and after the implementation of the GST i.e. the time frame that centred around 1 April 2015, the actual commencement date of the GST implementation. 
Table 4 below exemplifies the categorisation of campaigns, media, studies, instruments, policies and directives related to the GST as part of the discourse of nation building with their indication in underlined words:

TABLE 4. Examples of categorisation of the campaigns, media, studies, instruments, policies and directives related to the GST

\begin{tabular}{clc}
\hline & \multicolumn{1}{c}{ Extracts } & References \\
\hline 1. & $\begin{array}{l}\text { Malaysia sends a team to visit nations such as Australia, New Zealand and Indonesia to } \\
\text { further study the mechanics of GST. }\end{array}$ & Ar 11, para 5 \\
2. $\begin{array}{l}\text { The Royal Malaysian Customs and the Finance Ministry have done extensive research } \\
\text { on the GST. A recent study shows that Malaysia's model is indeed progressive. }\end{array}$ & Ar 12, para 28 \\
3. $\begin{array}{l}\text { a. the government had been reaching over 50,000 people daily through its } \\
\text { advertisements in the print and electronic media, as well as those placed on billboards }\end{array}$ & Ar 15, para 3 \\
and its postings on social networking sites like Facebook and Twitter. & \\
\hline
\end{tabular}

The news articles at the pre-GST stage when the former government was mulling over the feasibility of implementing the GST and was considering the various GST models in other GST compliant countries see a proliferation of noun phrases and clauses synonymous with "studies" such as "a research team to South Korea", "a team to visit nations such as Australia, New Zealand and Indonesia" and "studies done by the MoF and Customs". Such indication of the former government's careful planning with the mention of GST models in developed countries serves to bolster the people's confidence in the eventual implementation of the GST in the country's journey to achieving a developed nation as envisioned in Vision 2020. As such, the GST is constructed as an inevitable measure to transform Malaysia from a developing country to a fully developed country as evidenced by the successful implementation of the GST in other developed countries.

As the actual date of the GST implementation was drawing near, the news articles reported the various instruments, policies, legislatures and framework introduced by the former government in preparation for the GST implementation, including those related to false starts of the GST in the past. These documents are mainly cast in noun phrases such as "the 1993 Malaysian budget", "the 2009 GST Tax Bill", "laws and regulations", "Budget 2016" and "the National Transformation Programme". The ubiquitous mentions of these documents in the news articles serve as a strong reminder to the people of the former government's seriousness in implementing the GST and its commitment to sustaining nation building.

The news reports in the GST category also comprise a preponderance of noun phrases and nominalisations related to the former government's GST promotional and educational campaign and the various media used to reach out to the public. Instances of these linguistic features are "Government's GST Ad Campaign", "the campaign", "advertisements in the print and electronic media", "postings on social networking sites like Facebook and Twitter" and "on the television or on billboards".

The blitz of such campaigns and formulation of policies and legislatures by the former government are reminiscent of similar experience in countries such as Canada and New Zealand. Taking a leaf from these developed countries, the former government sent a clear message to the people about the impending implementation of the GST without further delay and at the same time, educated the public about the various benefits of the GST to the people and the country.

\section{THE IDENTIFICATION OF THE BENEFICIARIES OF THE GST}

An eminent feature of the discourse of nation building is the identification of the beneficiaries of the GST and nation building as evidenced by the reports in the GST news articles in which 
they are identified as generic categories such as "the people" and "the country". However, these generic categories cast mainly in noun phrases and clauses are at times inclusive and exclusive, among the former of which are "the rakyat", "the government", "benefit the people and the country", "the nation", "for the benefit of the rakyat and nation", "the people", "future generations" and "traders who have registered under the GST".

It is noteworthy that at times, the news articles further mark out the underprivileged, the poor, the average-income households and the deserving from the generic term "the people" as the main beneficiaries, hence identifying this category of the people by their economic status in exclusive terms and differentiating them from the rich. Examples of these are "lower income groups", "poor households", "the poor", "the low-income households", "low income households", "a household income of RM2,000 per month", "low- and middle-income earners", "poor households" and "poor families, children, senior citizens and the disabled".

Such dualistic representation of the beneficiaries sets up a dichotomy between the underprivileged and the rich, the majority and the minority. As such, the former government's message in the discourse of nation building was geared towards winning the hearts and minds of the majority of the people and at the same time portraying a responsible government of and for the people and the country.

Table 5 fleshes out the words used to identify and categorise the beneficiaries of the GST as discussed above with their indication in underlined words:

TABLE 5. Examples of categorisation of beneficiaries of the GST and nation building

\begin{tabular}{|c|c|}
\hline Extracts & References \\
\hline $\begin{array}{l}\text { 1. Sivanesan said this year's advertisements would focus on educating the public further } \\
\text { on the GST and how it would benefit future generations. }\end{array}$ & Ar 15 , para 12 \\
\hline $\begin{array}{l}\text { 2. In addition, RM3.0 billion is allocated for scholarships ... and RM1.2 billion for poor } \\
\text { families, children, senior citizens and the disabled. }\end{array}$ & Ar 17, para 4 \\
\hline $\begin{array}{l}\text { 3. With the revenue from GST, Najib said, the government would be able to implement } \\
\text { development projects .... and other assistance to the people. }\end{array}$ & Ar 23, para 9 \\
\hline
\end{tabular}

\section{DISCUSSION}

A series of false starts dated as far back as the 1990s preceded the eventual implementation of the GST in Malaysia on 1 April 2015. The delay is largely attributed to the strong opposition and the potential electoral cost to the former government if its implementation is not managed properly. This follows that the eventual implementation of the GST due to adverse economic climate has prompted the former government to embark on a nationwide education campaign to illuminate the public on the benefits of the GST to the country and people with a view to changing public perception and mindset from anxiety and opposition to ambivalence and acceptance, if not total embrace. On the slippery slope towards potential electoral backlash and obliteration, the government mounted the campaign leveraging multi-pronged strategies and discourses, one of which is the discourse of nation building, hence turning an education campaign on the GST into a political discourse of nation building to produce a positive portrayal of the government with an efficient economic developmental plan.

The propagation of the discourse of nation building seems to weave together several strategic moves to boost its persuasiveness and the people's conviction of the benefits of the GST to the country. Chief of these strategic moves are the construction and naturalisation of a dependent relationship between the government and the people; the equation of the GST with nation building and the collective responsibility of the government and the people in nation building. Ultimately, the interweaving of the GST and nation building can be viewed as the government's rallying call for the people to support the GST. 
The construction of a dependent relationship between the government and the people soon emerges with the portrayal of the government as the expert in economic matters and the people as the beneficiaries of the government's development plans. Frequent references to government officials and overseas GST study trips to "nations such as Australia, New Zealand and Indonesia" bear testimony to such claim of the government's expertise. In addition, other development plans mooted by the government as mentioned in the preceding sections have been used as an index of the government's economic experience and leadership in the discourse of nation building. Such development plans range from "infrastructure" to "transport, .... health care services, .... education, security, religious, .... social amenities, ... basic amenities ... and security".

The equation of the GST with the country's development can be inferred from news reports of the government's "extensive research on the GST" and study trips to other GST compliant countries, especially to developed countries, with a view to "studying the mechanics of GST" and replicating their successful models in managing a prosperous economy with the GST revenues. This link is made more apparent with the presence of positive words describing the GST as a "progressive", "effective and sustainable taxation system" drawn from the field of finance and economy which seem to suggest that the GST is synonymous with nation building and progress instead of a burden to the people. In no uncertain terms, the news reports foreground the importance of "the extra revenue" produced by the GST "to boost the nation's competitiveness". This clearly underlines the GST's pivotal role in generating revenues for the country's economic growth. By linking the GST to nation building, the government appears to capitalise on the people's desire and aspiration for economic progress.

The above attempt to link the implementation of the GST as central to Malaysia's vision to be a fully developed nation, a vision which all Malaysians embrace and can be proud of, leads to the working of the next strategic move i.e. the collective responsibility of the government and the people in developing the country. The invocation of the government's vision of nation building and a sense of collective responsibility and collective ownership of Malaysia appears to construct the ideology of the government and the people working hand in glove. This serves to co-opt the people to work with the government collectively to reap the fruits of a thriving economy of a fully developed nation as highlighted in the discourse of nation building discussed in the preceding section. The vision of a fully developed Malaysia becomes a goal and symbol for all Malaysians to strive for and a legacy that Malaysians will be proud of and willing to protect and defend for future generations to come.

Such an education campaign on the GST becomes a political instrument to clearly articulate the government's goals of nation building and hence, the discourse of nation building is inextricably interweaved with the political agenda of social solidarity and acceptance of the GST. It is conceivable that the GST education campaign and the discourse of nation building were employed not only to legitimise but also to safeguard the political power and position of the ruling elite as having economic experience and leadership. The persuasiveness of the discourse of nation building ultimately hinges on the people's conviction that the GST is implemented with a beneficent purpose as highlighted by the news articles, chief of which are the provision for the zero-rating and exemption of essential goods and services from the GST as well as the identification of the underprivileged, the poor and the average-income households as the main beneficiaries.

In retrospect, the discussion of this study benefits from a transition of governments after the $14^{\text {th }}$ General Election in May 2018 from the former pro-GST BN government to the new anti-GST PH government which has abolished and replaced the wide-ranging GST with the revived narrower Sales and Service Tax (SST). Reports and commentaries that attributed one of the main causes of PH's victory and BN's loss to the GST in particular and the high cost of living in general provide the study with retrospective insights into the people and the silent 
majority's resentment towards the GST despite the former government's massive campaign and discourse on the GST as well as positive news reports by the BN friendly and controlled mainstream media.

\section{CONCLUSION}

The discourse of nation building in the fourteen selected GST news articles by the mainstream media exemplifies how a change in the financial and economy landscapes of the country leads to the former government's push for the eventual implementation of the GST and its effort in effecting a corresponding change in the people's mindset to ease them into adapting themselves to and accepting the new economic reality.

The findings of this study clearly indicate a positive representation of the former government in the discourse of nation building in relation to the implementation of the GST. Such advantageous posturing through emphasising the positive features, benefits and beneficiaries of the GST implemented by a caring government and downplaying the weaknesses, demerits and criticism of the GST is engineered to co-opt the people into supporting the implementation of the controversial GST. Ultimately, it is geared towards effecting (trans)formation of the people's mental model of the GST from unfavourable to favourable through such glowing representation of the benefits of the GST.

The new Pakatan Harapan $(\mathrm{PH})$ government that took over from the previous BN government after the $14^{\text {th }}$ General Election on 9 May 2018 reiterated the efficiency of the GST as a tax regime. As admitted by the new Minister of Finance: "GST is an efficient system for the government but a burden to the people" (The Star Online 2018).

Unlike the successful implementation of the GST in developed countries, its implementation in Malaysia, a developing country, is perceived to pose a heavy financial burden to the average and poor households who have to grapple with bread and butter issues. This is because the country had not put in place sufficient measures to strengthen its financial and social safety net to cushion its impact on the lower income group. Herein lies the significance of this study on an issue that bears on all walks of life in Malaysia.

This study provides a framework for critical reading with a view to sensitising text consumers to the working of ideology and partisan reporting in media discourse on the contentious implementation of the GST in Malaysia. This is despite the subsequent replacement of the GST with the Sales and Services Tax (SST) by the new Pakatan Harapan government after the $14^{\text {th }}$ General Election in May 2018. As such, the findings of this study bear testimony to the importance of critical discourse analysis to uncover the manipulation of language by text producers to promote certain aspect of reality and ideology with a view to effecting changes in the text consumers' mindset.

\section{REFERENCES}

Aman, Idris. (2009). Discourse and striving for power: An analysis of Barisan Nasional's 2004 Malaysian general election manifesto. Discourse and Society. Vol. 20(6), 659-684.

Aysun, Akan (2011). A critical analysis of the Turkish press discourse against Non-Muslims: A case analysis of the newspaper coverage of the 1942 Wealth Tax. Middle Eastern Studies. Vol. 47(4), 605-621.

Berma, M. (2003). Towards the national vision policy: Review of the New Economic Policy and New Development Policy among the bumiputera communities in Sarawak. Kajian Malaysia. Vol. XXI(1\&2), 211-256.

Channel News Asia. (May 11, 2018). Commentary: Pakatan Harapan's successful campaign strategy, informed by data, powered by people. Retrieved August 1, 2018 from https://www.channelnewsasia.com/news/commentary/malaysia-election-ge14-pakatan-harapancampaign-strategy-10221738

Charteris-Black, J. (2006). Corpus Approaches to Critical Metaphor Analysis. New York: Palgrave.

Cheah, B. K. (2003). The bumiputera policy and nation-building. Kajian Malaysia. Vol. XXI(1\&2), 399-408. 
Creswell, J.W. (2007). Qualitative Inquiry and Research Design: Choosing among Five Approaches. Thousand Oaks, CA: Sage.

Diamond, J. W. \& Zodrow, G. R. (2008). Introduction: Is it time for fundamental tax reform. In Diamond, J. W. \& Zodrow, G. R. (Eds.). Fundamental Tax Reform: Issues, Choices, and Implications (pp. 1 - 26). Massachusetts: The MIT Press.

Fairclough, N. (1989). Language and Power. London: Longman.

Fairclough, N. (1992). Critical Language Awareness. London: Longman.

Fairclough, N. (1995). Critical Discourse Analysis: The Critical Study of Language. London and New York: Longman.

Fairclough, N. (2001). Language and Power ( $2^{\text {nd }}$ ed.). England: Pearson Education Limited.

Fairclough, N. (2015). Language and Power ( $3^{\text {rd }}$ ed.). Oxon: Routledge.

Farouk, A. F. A \& Husin, A. (2015). Development and social capital: A case study of selected Malaysian nongovernmental organizations (NGOs). Kajian Malaysia. Vol. 33(2), 25-42.

Fowler, R. \& Kress, G. (1979). Critical linguistics. In Fowler, Hodge, Kress \& Trew (Eds.), Language and Control (pp. 185 - 213). London: Routledge.

Fowler, R. (1991). Language in the News: Discourse and Ideology in the Press (pp. 25 - 26; 66 - 145). London: Routledge.

Gomez, E. T. (2003). Affirmative action and enterprise development in Malaysia: The new economic policy, business partnerships and inter-ethnic relations. Kajian Malaysia. Vol. XXI(1\&2), 59-104.

Gstmalaysiainfo. (May 11, 2015). Extra revenue gained from GST to boost nation's competitiveness: PM. Retrieved June 20, 2015 from http://gstmalaysiainfo.com/extra-revenue-gained-from-gst-to-boostnations-competitiveness-pm/

Hazis, F. S. (2009). The Politics of development in Sarawak. Akamemika. Vol. 77(Disember) 2009, 91-111.

Kailasam, A. (2015). Political expediencies and the process of identity construction: The quest for Indian identity in Malaysia. Kajian Malaysia. Vol. 33(1), 1-18.

Khoo, M. G. H. \& Bahiyah, A. H. (2019). Power structures and patterns of interaction in the Malaysian army. $3 L$ : The Southeast Asian Journal of English Language Studies. Vol 25(3), 46 - 64.

Lee, H. A. (2004). Development in Malaysia: Economics and politics of an idea. Akamemika. Vol. 64(Januari), $65-81$.

Louise, H. (2015). Policy Change, Public Attitudes and Social Citizenship: Does Neoliberalism Matter? Great Britain: Policy Press.

Low, C. C. (2017). A Malaysia of citizens: Ethnicity, membership and politics of merger. KEMANUSIAAN. Vol. 24(2), 1-30.

Mann, C. and Stewart, F. (2000). Internet Communication and Qualitative Research: A Handbook for Researching Online. London: Sage.

McKell, S. E. (2007). The language of economic rationalism: A critical discourse analysis of Howard's tax metaphors. Unpublished MPhil Thesis, University of Queensland, Australia.

Ministry of Finance Malaysia. (2017). 2018 Budget. Putrajaya: Percetakan Nasional Malaysia Berhad.

Nadhratunnaim, A. \& Surinderpal, K. (2019). Theologising the discourse of representation through 'faith' and religion in football news. 3L: The Southeast Asian Journal of English Language Studies. Vol 25(3), 150162.

Ministry of Finance Malaysia. (2017). Government Revenue 2018. Putrajaya: Percetakan Nasional Malaysia Berhad.

Omar, A. H. (2011). Empowering the humanities: A focus on language studies. KEMANUSIAAN. Vol. 18(2),101109.

Perdana Leadership Foundation. (2018). Malaysia's Development Plans and Policies. Retrieved December 23, 2019 from http://www.perdana.org.my/index.php/pms-of-malaysia/visual-timelines/malaysia-sdevelopment-plans-policies.

Porter, A. (2007). Women's issues in the Mulroney's era. In Blake, R. B. (Ed.). Transforming the Nation: Canada and Brian Mulroney (pp. 179-200). Canada: McGill-Queen's University Press.

Quinto, E. J. M. (2015). Physical and topical structures of manpower discourse: A contrastive rhetoric analysis in Southeast Asia. GEMA Online® Journal of Language Studies. Vol. 15(1), 91-110.

Rajandran, K. (2013). Metaphors for Malaysia's Economic Transformation Programme. Kajian Malaysia. Vol. 31(2), 19-35.

Ramanathan, R. \& Tan, B. H. (2015). Application of critical discourse analysis in media discourse studies. $3 L$ : The Southeast Asian Journal of English Language Studies. Vol. 21(3), 57 - 68.

Roberts, A. \& Rose, J. (1995). Selling the Goods and Services Tax: Government advertising and public discourse in Canada. Canadian Journal of Political Science. Vol. XXVIII(2), 311-330.

Rose, J. (2000). Making "Pictures in our Heads": Government Advertising in Canada. Westport, CT: Praeger Publishers. 
Teo, P. (2007). Weaving the fabric of a nation: An interdiscursive analysis of Singapore's clean and green campaigns. In Teo, P. \& Ho, C. (Eds.). Discourse in the Modern World: Perspectives and Challenges (pp. 163-181). Singapore: McGraw-Hill.

The Star Online. (May 9, 2018). Average wages of Malaysians on the rise. Retrieved August 6, 2018 from https://www.thestar.com.my/business/business-news/2018/05/09/average-wages-on-the-rise/

The Star Online. (July 20, 2018). Guan Eng wants big-ticket items to be taxed. Retrieved August 2, 2018 from https://www.thestar.com.my/business/business-news/2018/07/20/guan-eng-wants-big-ticket-itemstaxed/ (accessed 2 August 2018).

The Star Online. (July 20, 2018). No SST for essential items. Retrieved August 2, 2018 from https://www.thestar.com.my/news/nation/2018/07/20/no-sst-for-essential-items/

The Sun Daily. (May 10, 2018). High cost of living, Fake News Act among reasons why Pakatan Harapan won: Analysts. Retrieved August 1, 2018 from http://www.thesundaily.my/news/2018/05/10/high-cost-livingfake-news-act-among-reasons-why-pakatan-harapan-won-analysts

The World Bank. (2018). World Bank country and lending groups. Retrieved August 6, 2018 from https://datahelpdesk.worldbank.org/knowledgebase/articles/906519

United Nations. (1986). Declaration on the right to development. Retrieved June 12, 2015 from http://www.un.org/documents/ga/res/41/a41r128.htm

Vaara, E. (2014). Struggles over legitimacy in the Eurozone crisis: Discursive legitimation strategies and their ideological underpinnings. Discourse \& Society. Vol. 25(4), 500-518. 